\title{
Güzel Sanatlar Liselerinde Kullanılan Bireysel Ses Eğitimi Kitabındaki Alıştırma ve Eserlerin Hedef Davranış İlişkisinin İncelenmesi
}

\author{
DOI: $10.26466 /$ opus. 886567
}

\author{
$\underline{\text { Sevda Gürel }}^{*}$ \\ * Dr. Öğr. Üyesi, Ordu Üniversitesi, Müzik ve Sahne Sanatları Fakültesi, Ordu/Türkiye \\ E-Posta: tokersevda@gmail.com ORCID: $\quad$ 0000-0003-0496-7852
}

\begin{abstract}
Öz
Bu araştırmanın amacı, Güzel sanatlar liselerinde kullanılan 10. Sınıf Bireysel Ses Eğitimi kitabında bulunan alıştırmalar ve eserler arasındaki hedef davranış ilişkisini incelemektir. Mesleki müzik eğitiminin temellerini oluşturan Güzel Sanatlar Liselerinde ilk kez görüldü̈̆ü varsayılan ses eğitimi ders kitaplarının incelenmesi ve ses eğitimine katkı sağlamasına olanak sunması açısından önem taşımaktadır. Araştırmada Güzel Sanatlar Liseleri 10. Sınıf Bireysel Ses Eğitimi kitabında yer alan teknik çalışmalar ve eserler arasındaki ilişkinin incelenmesi amacıyla nitel araştırma yöntemlerinden doküman analizi modeli kullanılmıştır. Güzel Sanatlar Lisesi 10. sınıf Bireysel Ses Ĕ̆itimi ders kitabında bir oktav içerisinde yer alan alıştırmalara çok yer verilmiş olmasına karşın eserlerde az yer verilmiştir. Bu durumun tam tersine eserlerde en fazla yer verilen ses genişliği olan dokuzlu ses genişliği ile ilgili çok az alıştırmaya verildiği saptanmıştır. Alıştırmalarda makamların 4 makam çerçevesinde sinırl tutulduğ u buna bağh olarak hangi makamlarda alıştırma verildiyse o makamlara göre eser seçimleri yapıldı̆̆ı saptanmıştır. Kitapta makamsal eserler genel eser sayısının çoğunluğunu oluşturmaktadır. Alıştırmalarda ve eserlerde legato hem nitelik hem nicelik olarak yeterince yer verildiği sonucuna ulaşılmaktadır. Artikülasyon işaretlerinden staccato ise, alıştırma ve eserlerde sayıca çok az gösterilmektedir.
\end{abstract}

Anahtar Kelimeler: Bireysel Ses Ĕ̆itimi, Güzel Sanatlar Lisesi, Müzik Ĕ̆itimi. 


\title{
Investigation of the Relationship of Target Behavior of Exercises and Works in the Individual Voice Education Book Used in Fine Arts High Schools
}

\begin{abstract}
The aim of this research is to examine the target behavior relationship between the exercises and songs in the 10th Grade Individual Voice Education book used in fine arts high schools. It is important in terms of examining the audio training textbooks that are supposed to be seen for the first time in Fine Arts High Schools, which form the foundations of vocational music education, and allow them to contribute to vocal education. In the research, document analysis model, one of the qualitative research methods, was used in order to examine the relationship between the technical studies and songs in the Fine Arts High Schools 10th Grade Individual Sound Education book. Although the exercises included in one octave are included in the Fine Arts High School 10th grade Individual Sound Education coursebook, there is little space in the works. On the contrary, it has been determined that very few exercises have been given regarding the nine phonemes, which is the most frequently used interval in the works. In the exercises, it was determined that the with in four makams were limited, and therefore, the selection of songs was made according to which exercises were given. Modal works in the book constitute the majority of the general number of works. It is concluded that legato is given enough both qualitatively and quantitatively in the exercises and works. Staccato, one of the articulation signs, is shown very little in number in exercises and works.
\end{abstract}

Keywords: Individual Voice Education, Fine Arts High School, Music Education. 


\section{Giriş}

Geçmişten günümüze insanoğlu sesini kullanabilmeyi, nesneleri birbirine vurup ses yaratabilmeyi başardığında müzik de tarihini yazmaya başlamıştır. İlk çalgı insanın kendi sesidir (İlyasoğlu, 2001, s.1). “İnsan sesi aynı zamanda her yaşta ve koşulda değişiklik gösterebilen çok hassas yapıya sahip bir çalgıdır "(Töreyin, 2021, s.12).

"AGSL öğrencileri yaş olarak ses gelişim dönemini yaşamakta olan öğrencilerdir. Aynı zamanda seslerini solfej ve koro derslerinde sürekli olarak kullanmak durumundadırlar. $\mathrm{Bu}$ dönemde ses sisteminde meydana gelen değişim ve gelişimden olumsuz etkilenmemek için sesi zorlamadan, yumuşak fonasyonla ve küçük ses tonu ile ses eğitimi uygulamalarına ağırlık verilir. Böylece ses yapıları gelişirken, doğru ses üreterek kullanma alışkanlıkları kazanırlar. Bu beceri ile öğrencilerin ses sınırları içindeki tüm tonlarda eğitilmiş seslerin en önemli özelliği olan ses bütünlügünü oluşturmaları sağlanır. Dolayısı ile mutasyon dönemi ses özelliklerinden olan sesini kontrol edememe, sesinde bütünlük ve devamlılık sağlayamama ve sesini konuşurken ve şarkı söylerken gerektiği gibi rahat kullanamama durumu ortadan kalkar"(Akbulut, 2002).

"Ses eğitimi bireylere sesin oluşumu, kullanılması ve korunmasına ilişkin doğru davranış kazandırma süreci olarak tanımlamaktadır. Ses eğitiminde davranış alanları; sesi oluşturan öğeler ile ses eğitiminin amaçlarından kaynaklanır "(Töreyin, 2021, s.14).

Bireysel Ses Eğitimi Dersi Öğretim Programı, temel ses eğitiminin amacı doğrultusunda Türkçeyi doğru kullanma, solunum tekniklerini uygulama, sesini tanıma, doğru ve etkili kullanma, ait olduğu türün özelliklerine uygun olarak halk türkülerini, Türk sanat müziği eserlerini, marşları, Türk ve dünya müziklerinden çeşitli eserlerin seslendirilmesini kapsamaktadır. Güzel Sanatlar Liseleri'nde öğrenim gören öğrencilerin ergenlik döneminde bulundukları ve seslerinin değişim sürecinde olduğu unutulmamalıdır. Bu dönemde yapılan tüm ses eğitimi uygulamalarında bu değişim süreci her daim göz önünde bulundurulmalı ve bu doğrultuda doğru ve sağlıklı ses üretme, güzel ve etkili konuşma, şarkı söyleme, sesini doğru kullanma ve koruma alışkanlığının kazandırılması amaçlanmalıdır 
(M.E.B. Ortaöğretim Genel Müdürlüğü Anadolu Güzel Sanatlar Lisesi Bireysel Ses Eğitimi Öğretim Programı, 2016, s.4)

Ders kitapları eğitimde kullanılan en önemli öğretim araç-gereç ve materyalidir. Bu kitapların amacı, eğitim-öğretimde yer alan ilkeler doğrultusunda ve belirlenen bir program çerçevesinde öğrencilere hedefdavranışları kazandırmaktır.

Güzel Sanatlar Liseleri müzik bölümlerinde, "Müzikle Bütünlük" ilkesi esastır. Yaşam; bilgisel, felsefesel, sanatsal, bilimsel, tekniksel, endüstrisel ve ekonomiksel boyutlarıyla bir bütündür. Bu bütünlük içinde en büyük ağırlık hiç kuşkusuz "Sanatsal boyut"tadır. (Uçan, 1996, s.75)

Güzel sanatlar liselerinde ses eğitimi oldukça önemli bir yere sahiptir. Kullanılan ders kitapları, eğitimde hem bir amaç hem de bir araç olarak kullanılıp materyal görevini de üstlenmektedir. Liselerde verilen ses eğitimi, müzik eğitiminde hassasiyetini korumakla birlikte öğrencinin devinişsel, bilişsel ve duyuşsal anlamda da kendisine ve bilgilerine sürekli bir şeyler katmayı ön görür. Ses eğitiminde kullanılan ders kitabı şarkı söylemeyi öğretmekte bir araç olarak kullanıldığından içerisinde yer alan program ve bilgiler öğrenciye öğretilebilecek en doğru, en yeterli ve en sağlıklı içerikleri barındırması kritik detaylar arasında gösterilir. Güzel Sanatlar Liselerinde ses eğitimi için öğrenci 14-18 yaş grubundadır. Bu yüzden ses eğitimi, ses değişimi, gelişimi ve eğitimi açısından çok önemlidir. Buradan hareketle Güzel Sanatlar Liselerinde teknik açısından en yeterli, en çeşitli ve en verimli ses eğitiminin verilmesi önem arz etmektedir. Bu bağlamda problem cümlesi aşağıdaki gibidir:

\section{Problem Cümlesi}

Güzel Sanatlar liselerinde kullanılan 10. sınıf bireysel ses eğitimi ders kitabındaki alıştırmalar ve ilgili eserler arasındaki hedef davranış ilişkisi nasıldır?

\section{Alt Problemler}

1. Alıştırmalarda kullanılan ses genişlikleri ile eserlerin ses genişlikleri arasındaki hedef davranış ilişkisi nasıldır? 
2. Alıştırmalarda kullanılan makamsal alıştırmalar ile eserler arasındaki hedef davranış ilişkisi nasıldır?

3. Eserlerde kullanılan süsleme ve artikülasyon işaretleri ile alıştırmalar arasındaki hedef davranış ilişkisi nasıldır?

\section{Araştırmanın Amacı ve Önemi}

$\mathrm{Bu}$ araştırmanın amacı, Güzel sanatlar liselerinde kullanılan 10. Sınıf Bireysel Ses Eğitimi kitabında bulunan alıştırmalar ve eserler arasındaki hedef davranış ilişkisini incelemektir. Ülkemizde mesleki müzik eğitiminin temellerini oluşturan Güzel Sanatlar Liselerinde ilk kez görüldüğü varsayılan ses eğitimi derslerinin gerçekleştirilmesinde kullanılan ders kitaplarının incelenmesine, ses eğitimine katkı sağlamasına olanak sunması açısından önem taşımaktadır.

\section{Sinırlılıklar}

Kullanılan kaynaklar Ortaöğretim Güzel Sanatlar Lisesi 10. sınıf Bireysel Ses Eğitimi kitabı ile sınırlıdır.

\section{Yöntem}

Araştırmada Güzel Sanatlar Liseleri 10. Sınıf Bireysel Ses Eğitimi kitabında yer alan alıştırmalar ve eserler arasındaki ilişkinin incelenmesi amacıyla nitel araştırma yöntemlerinden doküman analizi modeli kullanılmıştır.

"Araştırma kapsamında incelenen konu ile ilgili olgu ve olaylar hakkında bilgi içeren yazılı belgelerin analiz edilmesiyle veri sağlanmasına doküman incelemesi denilmektedir. Araştırma yapılan alanla ilgili pek çok bilgi görüşme ve gözlem yapmaya gerek kalmaksızın belge inceleme yoluyla elde edilebilir. Bu sayede araştırmacı zaman ve kaynak tasarrufu sağlamış olur. Hangi dokümanın önemli olduğu ve veri kaynağı olarak kullanılabileceğine araştırma konusuna bakarak karar vermek gerekir" (Yıldırım ve şimşek, 2008, s.188). 


\section{Verilerin Toplanması ve Analizi}

Veriler, ortaöğretim Güzel Sanatlar Liseleri ses eğitimi ve öğretimi için 2019 yılında basılan ve üçüncü baskısında olan 10. Sınıf Bireysel Ses Eğitimi kitabı EBA sistemi üzerinden dijital ortamdan elde edilmiştir. Veriler, doküman analiz aşamalarından analize konu olan verilerden örneklem seçme ve sayısallaştırma aşamasından yüzde dağılım yoluyla analiz edilmiştir.

“Örneklem seçme: Doküman incelemesine dayalı araştırmalarda, tüm doküman verisinin bir bütün olarak analize konu olması mümkün olmayabilir. Bu nedenle, çoğu zaman araştırmacılar, eldeki veri setinin içinden bir örneklem oluşturmaya çalışır"(Yıldırım ve Şimşek, 2011, s.197). "Sayısallaştırma: Dokümanlardan elde edilen verinin mutlaka sayısallaştırılması veya nicelleştirilmesi gerekmeyebilir. Araştırmacı, saptadığı kategoriler ve analiz birimi doğrultusunda yaptığı analizden sonra bulduğu sonuçları, rahatlıkla düzyazı şeklinde de rapor edebilir “(Yıldırım ve Şimşek, 2011, s.200).

\section{Bulgular ve Yorum}

$\mathrm{Bu}$ bölümde problem durumu kısmında sıralanmış alt problem cümlelerine göre bulgular sunulmaya çalışılacaktır.

Birinci Alt Probleme Yönelik Bulgular ve Yorumlar: Alıştırmalarda kullanılan ses aralıkları ile eserlerin ses aralıkları arasındaki hedef davranış ilişkisi nasıldır?

Elde edilen verilere göre, bireysel ses eğitimi kitabında alıştırmaların büyük çoğunluğunun sekizli ses aralığında tercih edildiği görülmektedir. Tam beşli ve tam dörtlü ses aralığı içeriğini kapsayan 14 alıştırma bulunmaktadır. Tablo 1'de görüldüğü gibi dokuzlu ses aralığı eserlerde en sık tercih edilen ses aralığı olmasına rağmen alıştırmalarda çok az tercih edilmiştir. Benzer durumun sekizli ses aralığı kullanımında tam tersi şekilde olduğu görülmektedir. Bu durum ile ilgili olarak, öğrenci bir eğitim-öğretim yılında dokuzlu ses aralığında yeterince alıştırma yapamadan, seslendireceği şarkıların büyük çoğunluğu bu ses aralığında olacaktır. Bu bağlamda öğrenci, sekizli ses aralığı arasında çok egzersiz-az 
eser, dokuzlu ses aralığında az egzersiz-çok eser seslendirmek durumundadır. Buradan hareketle eğitim alan bireylerin dokuzlu ses aralığını içeren eserlerde diğer aralıklara göre nispeten daha fazla zorlanacağı, yeterli hazır bulunuşlukta olamayacağı düşünülebilir.

Diğer taraftan verilere göre onlu, on birli ve on dörtlü ses aralığında hiçbir alıştırma bulunmamaktadır. Buna karşın toplam 8 eser bu ses aralıklarında tercih edilmiştir. Öğrencilerin gerekli çalışma ve alıştırmaları yapmadan eserlerde bu ses aralıklarına göre şarkı söylemesinin, eğitim ilkelerinden kolaydan zora ilkesi ile örtüşmediği düşünülmektedir.

Tablo 1. Alıştırmalar ve Eserlerin Ses Genişliği Dă̆ılımı

\begin{tabular}{lllll}
\hline Ses genişliği & Alsştırmalar & \multicolumn{3}{l}{ Eserler } \\
\cline { 2 - 5 } & $\mathbf{f}$ & $\mathbf{\%}$ & $\mathbf{f}$ & $\mathbf{\%}$ \\
\hline Büyük ikili & 2 & 5.8 & - & - \\
Büyük üçlü & 6 & 17.6 & - & - \\
Tam dörtlü & 1 & 2.9 & - & - \\
Tam beşli & 8 & 23.5 & 1 & 3,2 \\
Büyük altılı & 1 & 2.9 & 3 & 9,6 \\
Büyük yedili & - & - & 2 & 6,4 \\
Sekizli & 13 & 38 & 6 & 19,3 \\
Dokuzlu & 3 & 9 & 11 & 35,4 \\
Onlu & - & - & 4 & 12,9 \\
On birli & - & - & 3 & 9,6 \\
On dörtlü & - & - & 1 & 3,2 \\
Toplam & 34 & 100 & 31 & 100 \\
\hline
\end{tabular}

İkinci Alt Probleme Yönelik Bulgular ve Yorumlar: Alıştırmalarda kullanılan makamsal alıştırmalar ile eserler arasındaki hedef davranış ilişkisi nasıldır?

Tablo 2. Alıştırmalar ve Eserlerin Makamlara Göre Dağılımları

\begin{tabular}{lllll}
\hline Makamlar & Aliştırmalar & \multicolumn{3}{l}{ Eserler } \\
\cline { 2 - 5 } & $\mathbf{f}$ & $\mathbf{6}$ & $\mathbf{f}$ & $\mathbf{\%}$ \\
\hline Hicaz & 1 & 25 & 4 & 20 \\
Hüseyni & 1 & 25 & 6 & 30 \\
Kürdi & 1 & 25 & 5 & 25 \\
Nihavent & 1 & 25 & 4 & 20 \\
Toplam & 4 & 100 & 20 & 100 \\
\hline
\end{tabular}

Tablo 2 incelendiğinde, makamların alıştırmalarda birbirlerine göre sayıca eşit dağıldığı görülmektedir. Eserlerde ise makamların oranları 
yakın olmakla birlikte, en çok tercih hüseyni makamındaki eserlere yapılmıştır. Bireysel ses eğitimi kitabında bir önceki tabloda (Tablo 1) görüldüğü gibi toplam 31 eser yer almaktadır. Bu eserlerin yarısından fazlası makamsal eserlerden oluşmaktadır. Sayıca fazla yer alan makamsal eserlere göre alıştırma sayısının çok düşük olduğu görülmektedir. Güzel Sanatlar Liselerinde verilen diğer teorik ve uygulamalı derslerde öğrencilerin burada yer alan makamları öğrenmiş olabileceği düşünülmektedir.

Bilişsel ve duyuşsal olarak diğer derslerde öğrencilere bu makamlar öğretilse de, bireysel ses eğitimi dersinde devinişsel olarak bu makamlarla ilgili öğrenciden şarkı söylemesi beklenmektedir. Öğrencinin yeterli alıştırma yapmadan eser seslendirmesinin, öğrenme ve olgunlaşma için temel unsur olan hazır bulunuşluk kavramı bağlamında uygun olmayacağı öngörülmektedir.

Üçüncü Alt Probleme Yönelik Bulgular ve Yorumlar: Eserlerde kullanılan süsleme ve artikülasyon işaretleri ile alıştırmalar arasındaki hedef davranış ilişkisi nasıldır?

Tablo 3. Alıştırmalar ve Eserlerin Süslemeler ve Artikülasyon İşaretlerine Göre Dă̆ılımı

\begin{tabular}{lllll}
\hline Süslemeler/Artikülasyon & Alıstırmalar & \multicolumn{3}{l}{ Eserler } \\
\cline { 2 - 5 } & $\mathbf{f}$ & $\mathbf{\%}$ & $\mathbf{f}$ & $\mathbf{\%}$ \\
\hline Tril & - & - & 1 & 3,2 \\
Çarpma & - & - & 1 & 3,2 \\
Staccato & 2 & 5,8 & 1 & 3,2 \\
Legato & 26 & 76,4 & 27 & 87,5 \\
Toplam & 34 & 100 & 31 & 100 \\
\hline
\end{tabular}

Elde edilen veriler doğrultusunda, alıştırma ve eserlerde en çok legato artikülasyon işareti yer almaktadır. Eserleri seslendirirken hecelerin notalara göre uyumunu sağlamak için legato işareti eklenmektedir. Bu duruma öğrencilerin de devinişsel olarak hazır olmasını sağlamak için alıştırmalar ve eserlerde benzer oranlarda legato artikülasyonu kullanıldığı düşünülmektedir. Bu bağlamda bireyde legato işaretinin uygulanıp, seslendirilmesinde kalıcı ve tam öğrenmenin gerçekleşebileceği öngörülmektedir. Benzer tercih oranları staccato 
artikülasyonunda bulunmamaktadır. Hem alıştırmalarda hem de eserlerde sayıca çok az yer almaktadır. Bu durumun öncelikle eserlerde kullanımının az olmasından veya Türk Halk Müziği ve Türk Sanat Müziği eserlerinin notaya alınırken staccato artikülasyonu ile seslendirilmesi gereken yerler için notada belirtilmediğinden kaynaklı olabileceği düşünülmektedir.

Süsleme işaretlerinden, tril ve çarpmaların sadece eser notalarında tercih edildiği, alıştırma notalarında tercih edilmediği tablodan (Tablo.3) anlaşılmaktadır. Yine artikülasyon işaretleri ile benzer bir şekilde ses eğitiminde kullanılmak için düzenleme yapılan veya yeniden notaya alınan eserlerde şarkı söylerken uygulanan vibrato, tril ve çarpma gibi süslemelerin, notalara eklenmesinde öncelik sırasına göre gerilerde tercih edildiği düşünülmektedir. Bu bağlamda, Güzel Sanatlar Lisesi öğrencileri bireysel ses eğitimi kitabına ile çalıştıklarında, uygulamadaki şarkı söyleme artikülasyonu ve süslemeleriyle, notada bulunmayan işaretleri fark etmekte güçlük çekebileceği ön görülmektedir.

\section{Sonuç, Tartışma ve Öneriler}

Bu çalışmada, Güzel Sanatlar Liselerinde 10. Sınıf Bireysel Ses Eğitimi ders kitabı içeriği (ses aralıkları, makamlar, süslemeler/artikülasyon) incelenmiştir. Elde edilen bulgular ve yorumlardan yola çıkılarak aşağıdaki sonuçlara ulaşılmıştır.

Güzel Sanatlar Lisesi 10. sınıf Bireysel Ses Eğitimi ders kitabında sekizli ses aralığını içeren alıştırmalara çok yer verilmiş olmasına karşın eserlerde az yer verilmiştir. Bu durumun tam tersine eserlerde en fazla yer verilen ses aralığ1 olan dokuzlu ses aralığ1 ile ilgili çok az alıştırma verildiği saptanmıştır. Alıştırmalarda ses aralığı eğitimi olarak hiç yer verilmeyen onlu, on birli ve on dörtlü ses aralığına sahip çalışmalara, eserlerde nispeten sayıca fazla bir şekilde yer verildiği sonucuna ulaşılmıştır. Laçin ve Baran (2020) çalışmasında, TSM eserlerinden "Kırmızı Gülün Adı Var" ve seçilen marşların 10. Sınıf öğrencilerinin ses aralıklarının çok üzerinde olduğunu vurgulamaktadır. Bu vurguya ek olarak, bu çalışmada saptanan alıştırmalardaki uzak aralıklı çalışmaların eksikliğinin, öğrencileri uygulama esnasında zorlayacağı öngörülmektedir. Genel 
olarak eserler ve çalışılan alıştırmalar arasında nicel olarak bir dengenin sağlandığı görülmüştür.

Alıştırmalarda makamların 4 makam çerçevesinde sınırlı tutulduğu buna bağlı olarak hangi makamlarda alıştırma verildiyse o makamlara göre eser seçimleri yapıldığı saptanmıştır. Kitapta makamsal eserler genel eser sayısının çoğunluğunu oluşturmaktadır. Bu duruma göre verilen makamsal alıştırma sayısı öğretilen makam sayısına eşittir. Bu bağlamda öğrencilerin makamsal eser seslendirmek için yeterli devinişsel hazırlıkta bulunamayacağı düşünülmektedir. Laçin ve Baran (2020) yaptıkları çalışmada, özellikle TSM eserlerinin seslendirilmesinde özel bir tavır ve üslup ile icra edilmesi gerektiğini, 10. sınıf öğrencilerin bu eserler seçilirken seviyelerinin dikkate alınmadığını belirtmişlerdir. İki araştırma arasında makamsal eserlerin icrasına ve çalışılmasına yönelik yeterince bilgilendirme yapılmadığına yönelik paralellik bulunmaktadır.

Şarkı söylemek için hece ve nota uyumunu sağlamak adına en büyük araç olarak legato artikülasyonun kullanıldığı bilinmektedir. Bu duruma benzer bir şekilde Bireysel Ses Eğitimi kitabında alıştırmalarda ve eserlerde legato hem nitelik hem nicelik olarak yeterince yer verildiği sonucuna ulaşılmaktadır. Artikülasyon işaretlerinden staccato ise, alıştırma ve eserler sayıca çok az gösterilmektedir. 10. sınıf öğrencilerinin bu artikülasyon işaretlerini teorik olarak diğer derslerde de kazandığını düşünecek olursak, devinişsel olarak Bireysel Ses Eğitimi dersinde uygulama imkânın yeterince gerçekleşemeyeceği düşünülmektedir. Toptaş ve Sönmez (2015) yaptıkları çalışmada, bireysel ses eğitimi öğretmenlerinin görüşlerine başvurmuşlardır. Öğretmenlerin görüşlerine göre artikülasyon işaretleri öğretiminin "sonucuna ulaşamadıklarını" belirtmişler ve öğrenci ile bire bir ders yapılmaması, ders saatinin yetersizliği durumlarından bu durumun etkilendiği sonucuna ulaşılmıştır. Bu sonuçlarla paralel olarak hem kitaplarda bu kazanımlar gerçekleşmesi için teorik alt yapının yetersizliği hem uygulamadaki öğretmenlerin çeşitli sıkıntıları dile getirmesi, bireysel ses eğitimi dersinde artikülasyon ve süsleme icrasının yetersiz olabileceği sonucuna ulaşılmaktadır. 


\section{Öneriler}

1. Bireysel Ses Eğitimi kitaplarında dokuzlu ses aralıklarını içeren alıştırmalara çok az yer verildiği görülmüştür. Bu ses aralığının eserlerde çok fazla kullanılmasından dolayı öğrencilere yeterli hazırlığı sunma imkânı veremeyeceği düşünülmektedir. Buradan hareketle kitabında alıştırma bölümlerinde dokuzlu ses aralığ1 içerisinde uygulanan alıştırma sayıları artırılmalıdır.

2. Makamsal şarkılar tonal şarkılara göre kitapta daha fazla yer almaktadır. Alıştırmalarda ise tonal alıştırmalar çok fazla, makamsal alıştırmalar oldukça azdır. Buradaki çelişkiyi azaltmak ve öğreticiliği davranış değişikliğini artırmak adına makamsal alıştırmalara daha fazla yer verilmelidir.

3. Şarkıların notalarındaki süsleme ve artikülasyon işaretleri bilgilerine yeterince yer verilmediği görülmektedir. Bu durumdaki belirsizliği azaltmak adına yeniden notaya alınan halk şarkıları veya düzenlemelerde, uygulama esnasında gerçekleşen süsleme ve artikülasyonları da nota üzerinde sembol anlamında eklemeleri önerilebilir. 


\title{
EXTENDED ABSTRACT
}

\section{Examination of the Target Behavior Relationship Between Exercises and Songs in the Individual Voice Training Textbook Used in Fine Arts High Schools}

\author{
Sevda Gürel \\ Ordu University
}

Individual Voice Training Course Curriculum includes using Turkish language correctly, applying breathing techniques, recognizing and using own voice correctly and effectively in purpose of basic voice education; singing folk songs, Turkish art music songs, anthems, various songs from Turkish and world music in accordance with the characteristics. It should not be forgotten that the students studying at Fine Arts High Schools are in adolescence period, and their voices are in the process of change. This change process should always be taken into consideration in all voice training practices carried out in this period, and in this direction it should be aimed to gain the habit of producing correct and healthy voice, speaking beautifully and effectively, singing, using and protecting the voice correctly.

Textbooks are the most important teaching tools and materials used in education. The purpose of these books is to give students target-behavior skills in line with the principles in education and within the framework of a determined curriculum. Voice education has a very important place in fine arts high schools. The textbooks have important role in this education as a goal and a tool as well. The voice education given in high schools aims to bring students psychomotor, cognitive and emotional gains, and forces them to add something to their knowledge and skill constantly. Since the textbook used in vocal education is used as a tool for teaching singing, it is among the critical details that it should has the most accurate and sufficient content that can be taught to the student. Students are in the 1418 age group for voice training in Fine Arts High Schools. Therefore, voice training is very important in terms of voice change, development and education. From this point of view, it is important to provide the most 
adequate, most diverse and efficient voice education in terms of technique in Fine Arts High Schools. AGSL students are in a period of the sound development as well. They have to use their voices continuously in solfege and choir lessons. In this period, in order not to be adversely affected by the change and development in the voice system, voice training practices are emphasized without forcing the voice, with soft phonation and small tone of voice. Thus, while their sound structure develops, they gain the habit of producing the right sound. With this skill, students are provided to create sound integrity which is the most important feature of sounds trained in all tones within the sound limits. Therefore, the situation of not being able to control his/her voice which is one of the voice characteristics of the mutation period, not being able to provide integrity and continuity in his/her voice, and not being able to use his/her voice comfortably while speaking and singing disappear. The purpose of this research is to examine the target-behavior relationship between the exercises and songs in the 10th Grade Individual Voice Training textbook used in Fine Arts High Schools. It is important in terms of enabling the examination of the textbooks used in the voice training lessons, which are supposed to be seen for the first time in Fine Arts High Schools, which form the foundations of professional music education in our country, and to contribute to voice education. The resources used are limited to the Secondary Education Fine Arts High School 10th grade Individual Voice Education book. In the research, document analysis model, one of the qualitative research methods, was used in order to examine the relationship between the exercises and songs in the Fine Arts High Schools 10th Grade Individual Voice Education book. The data were obtained from the digital environment through the EBA system of the 10th Grade Individual Voice Education book, which was published in 2019 and is in its third edition, for secondary education program of Fine Arts High Schools. The data were analyzed through percentage distribution from the stage of selecting samples from the data subject to analysis and digitizing from the document analysis stages. Fine Arts High School 10th grade Individual Voice Training course book includes exercises that include octal vocal range, but little space is given in the songs. On the contrary, it was determined that very few exercises were given about the ninth voice range, which is the most used voice range in the songs. It has been 
concluded that studies with ten, eleven and fourteen vocal ranges, which are not included in the exercises as vocal range training, are relatively more numerous in the songs. In the exercises, it was determined that the maqams were limited within the framework of 4 maqams, and accordingly, songs were selected according to the makams in which the exercises were given. The maqam works in the book constitute the majority of the general number of songs. Accordingly, the number of maqam exercises given is equal to the number of maqams taught. In this context, it is thought that students will not be able to make sufficient psychomotor preparation to perform a maqam piece. It is known that legato articulation is used as the greatest tool to provide syllable and note harmony for singing. Similar to this situation, it is concluded that legato is sufficiently included both in terms of quality and quantity in the exercises and songs in the Individual Voice Training book. Staccato, which is one of the articulation signs, is shown very little in number of exercises and songs. Considering that 10th grade students theoretically gain these articulation signs in other lessons, it is thought that the opportunity to apply dynamically in Individual Voice Training course will not be enough.

It has been observed that very little space is given to exercises that include nine-voice intervals in Individual Voice Training books. It is thought that this sound range will not be able to provide sufficient preparation to the students due to the excessive use of these sound intervals in the songs. From this point of view, the number of exercises applied in the nine-voice range should be increased in the exercise sections of the book. The maqam songs take place more in the book than the tonal songs. In the exercises, on the other hand, there are many tonal exercises and very few maqam exercises. In order to reduce the contradiction here and increase the instructional behavior change, more place should be given to the modal exercises.

It is seen that the information on ornamentation and articulation marks in the notes of the songs is not sufficiently included. In order to reduce the ambiguity in this situation, it can be suggested that in folk songs or arrangements that are re-noted, they should also add the ornaments and articulations that took place during the application in the sense of symbols on the note. In order to reduce the uncertainty in this situation, it may be 
useful to show the ornaments and articulations that occur during the implementation of re-noted folk songs or arrangements with symbols on the note.

\section{Kaynakça / References}

Akbulut, Y. (2002). Anadolu Güzel Sanatlar Liseleri için koro ders kitabı hazırlık sinıfi. Ankara: Akşam Sanat Okulu Matbaası.

Güzel Sanatlar Lisesi Bireysel Ses Eğitimi Öğretim Programı. (2016). M. E. B Ortä̈ğretim Genel Müdürlüğ̈̈̈. Ankara: M. E. B Yayınları.

Bayraktar, F. ve Bayraktar, M. ve Akın, S. (2019). Güzel sanatlar lisesi bireysel ses eğitimi 10. sınıf ders kitabı. Ankara: MEB.

İlyasoğlu, E. (2001). Zaman içinde müzik. İstanbul: Remzi Kitabevi.

Laçin, G. ve Baran, M. (2020). Güzel Sanatlar Lisesi 10. sınıf bireysel ses eğitimi kitabında yer alan eserlerin incelenmesi. Balkan Müzik ve Sanat Dergisi, 2(2), 27-45. DOI:10.47956/bmsd.787046

Toptaş, B. ve Sönmez, A. (2015). Güzel Sanatlar Liseleri müzik bölümlerinde bireysel ses eğitimi dersinin doğru ve etkili konuşma becerisine etkisi. İnönü University Journal of Culture and Art, 1(1), 1-15.

Töreyin, A. M. (2021). Ses eğitiminde metot ve uygulama. Ankara: Özyurt Matbaacilık.

Uçan, A. (1996). 20.Yüzyıl eşiğinde Türkiye AGSL müzik Bölümleri; Genel Durum -Sorunları-Çözümler. 1. Ulular Arası A.G.S. L Müzik Bölümleri Sempozyumu, Bursa: Uludağ Üniversitesi Yayınları.s.75

Yıldırım, A. ve Şimşek, H. (2011). Sosyal bilimlerde nitel araştırma yöntemleri. Ankara: Seçkin Yayıncılık.

\section{Kaynakça Bilgisi / Citation Information}

Gürel, S. (2021). Güzel Sanatlar Liselerinde kullanılan bireysel ses eğitimi kitabındaki alıştırma ve eserlerin hedef davranış ilişkisin incelenmesi. OPUS-Uluslararası Toplum Araştırmaları Dergisi, 18(Eğitim Bilimleri Özel Sayıs1), 4671-4685. DOI: 10.26466/opus. 886567 . 